\title{
Effect of Carbon Source on Morphology and Histodifferentiation of Araucaria angustifolia Embryogenic Cultures
}

\author{
Neusa Steiner ${ }^{1}$, Felipe do Nascimento Vieira ${ }^{1}$, Sara Maldonado $^{2}$ and Miguel Pedro \\ Guerra $^{1 *}$ \\ ${ }^{1}$ Laboratório de Fisiologia do Desenvolvimento e Genética Vegetal; Departamento de Fitotecnia; Centro de \\ Ciências Agrárias; Universidade Federal de Santa Catarina (UFSC); C. P. 476; 88040-900; \\ mpguerra@cca.ufsc.br; Florianópolis - SC - Brasil. ${ }^{2}$ Instituto de Recursos Biológicos; CIRN-INTA, 1712; Castelar - \\ Argentina
}

\begin{abstract}
The aim of the present work was to establish in vitro conditions for the induction, stabilization and proliferation of embryogenic cultures of A. angustifolia. Pre-cotyledonary staged zygotic embryos inoculated BM medium supplemented with $5 \mu M$ 2,4- D, $2 \mu M$ BAP and Kin, and 3\% maltose or sucrose resulted in $66.7 \%$ induction rate. The rate of induction of embryogenic cultures was affected by the carbon source, as well the multiplication and morphology of the embryogenic cultures. Embryogenic cultures maintained in BM medium with maltose presented bipolar morphology. Globular somatic embryos were obtained BM medium with 9\% (PEG) and (9\%) maltose. These results could establish an in vitro regenerative protocol towards the conservation and improvement of this important species.
\end{abstract}

Key words: Cell competence, somatic embryogenesis, carbohydrate, conifers

\section{INTRODUCTION}

In conifers, remarkable advances were recently established in the protocols of somatic embryogenesis as is the case of Pinus strobus (Klimaszewska et al., 2000) and Pinus pinaster (Ramarosandratana et al., 2001), as well as for conifers threatened with extinction as Cedrus libani in Lebanon (Khuri et al., 2000) and Araucaria angustifolia (Bert) O. Kuntze (Silveira et al., 2002). This last species, native to Southern Brazil was severely logged during the last century. It presents a long life cycle their seeds are highly recalcitrant and the conventional methods for vegetative propagation are difficult to establish (Guerra et al., 2000).

Conifers present zygotic polyembryogenesis restricted to the early stages of embryo development. This remarkable adaptive and evolutionary mechanism may occur in response to the fertilization of the four ovules and/or by the cleavage of a single pro-embryo resulting in multiple embryos (Gifford and Foster, 1989). The reconstitution of polyembryos in vitro may occur by means of the somatic polyembryogenesis (Gupta and Grob, 1995).

Somatic embryogenesis relies in a sequence of steps including induction, proliferation,

\footnotetext{
* Author for correspondence
} 
maturation, germination and finally ex vitrum acclimatization (Bozhkov et al., 2002). During embryogenesis, along with differentiation of apical and basal regions (morphogenesis), which establishes a polar axis, primary meristematic tissues and apical meristem are differentiated (histogenesis). For most coniferous species including $A$. angustifolia, the mechanism and proper regulation of somatic embryo formation has not been completely explained. The study of in vitro morphogenetic events is essential for the elucidation of control points associated with the induction and control of somatic embryogenesis in plants. In this study, we investigated some aspects associated with the induction, proliferation, development, and morphogenesis of embryogenic cultures of Araucaria angustifolia, with emphasis on the effect of carbohydrate source in the development of globular somatic embryos as fundamental steps towards a somatic embryogenesis protocol. The present work is part of a study involving the use of biotechnological tools for the conservation and improvement of this important and endangered Brazilian conifer.

\section{MATERIAL AND METHODS}

\section{Plant material}

From November 2002 to February 2003, immature female cones of $A$. angustifolia were collected from three plants of a natural population located at Bom Retiro County, Santa Catarina State, Southern Brazil. The cones were stored at $4^{\circ} \mathrm{C}$ until has processing. The seeds were then isolated from the cones, immersed in alcohol (70\%) $2 \mathrm{~min}$; in sodium hypochlorite (2\%) for $20 \mathrm{~min}$ and then washed three times with sterile water. In aseptic chamber, the immature zygotic embryos were isolated under stereomicroscope.

\section{Induction of embryogenic cultures}

The developmental stage of zygotic embryos used as explants was assessed at every collection time by staining with acetocamine (1\%) and Evan's blue $(0.5 \%)$ according to (Durzan, 1988). These explants were inoculated BM medium (Gupta and Pullman, 1991) supplemented with casein hydrolysate $\left(0.5 \mathrm{~g} \mathrm{~L}^{-1}\right)$, L-glutamine $\left(1 \mathrm{~g} \mathrm{~L}^{-1}\right)$, myo-inositol $\left(1 \mathrm{~g} \mathrm{~L}^{-1}\right), 2,4-\mathrm{D}(5 \mu \mathrm{M})$, BAP (2 and $4 \mu \mathrm{M})$ and $\mathrm{Kin}(2 \mu \mathrm{M})$ and sucrose $(3 \%)$ or maltose (3\%). These compounds were filter-sterilized and added to the culture medium after autoclaving at $121^{\circ} \mathrm{C}$ for $15 \mathrm{~min}$. The $\mathrm{pH}$ of the culture medium was adjusted to 5.8 before adding phytagel ${ }^{\circledR}$ $(0.25 \%)$. Explants were inoculated in Petri dishes $(90 \times 10 \mathrm{~mm})$ containing $25 \mathrm{~mL}$ of culture medium. The cultures were incubated in the dark at $25 \pm 2^{\circ} \mathrm{C}$.

\section{Proliferation of embryogenic cultures}

After 30 days, the proliferating embryogenic cultures were subcultured to the same culture medium with the concentration of plant growth regulators reduced to half, subcultured three times every 20 days and then considered stabilized. The quality of cultures was evaluated by cytochemical procedures under light microscope based on acetocarmine and Evan's blue staining.

\section{Somatic embryo development}

Samples of $500 \mathrm{mg}$ of embryogenic cultures originated the culture medium supplemented with sucrose $(3 \%)$, or maltose $(3 \%)$ and with $2,4-\mathrm{D}$ $(2 \mu \mathrm{M}), \quad \mathrm{BAP}$ and Kin $(0.5 \mu \mathrm{M}$ each) were subcultured Petri dishes containing $25 \mathrm{ml}$ of $\mathrm{BM}$ culture medium supplemented with $\mathrm{Kin}(1 \mu \mathrm{M})$, PEG (9\%), maltose (9\%) and sucrose (3\%). The cultures were incubated in the dark at $25 \pm 2^{\circ} \mathrm{C}$ and subcultured every 20 days. Before submitted to maturation treatment, the cultures were evaluated according their morphological features based on von Arnold et al. (1996) and on cytochemical evaluations with acetocarmine and Evan's blue.

\section{Experimental design and statistical analysis}

All experiments were established in a completely randomized blocks design. The treatments were performed in triplicate and the data were submitted to the analysis of variance. Student-NewmanKeuls mean separation test was used to indicate significant differences (5\%).

\section{RESULTS AND DISCUSSION}

\section{Somatic embryogenesis initiation and proliferation responses}

In this study, the relationship between collecting time and developmental stage of zygotic embryo was difficult to establish. For the same collecting date, embryos used as explants from the three genotypes reached different developmental stages, i.e. while proembryos were found in genotype A, 
globular and torpedo embryos were present in genotype $\mathrm{B}$ and $\mathrm{C}$, respectively (Table 1). Different maturation times of cones could explain there differences because A. angustifolia was a native non-domesticated species, possibly with two or more botanical varieties cohabiting in the same region (Reitz, 1966).
Differences in zygotic embryo maturation had direct effect in embryogenic induction rate (Table 2 ). In conifers, in vitro embryogenic induction rate was associated with several factors including culture environment, choice of explants, genotype and plant growth regulators (Zoglauer, 2003; Stasolla et al., 2003).

Table 1 - Developmental stages of Araucaria angustifolia zygotic embryos from three different genotype in different colleting times.

\begin{tabular}{c|c|c|c}
\hline \multirow{2}{*}{ Genotype } & \multicolumn{3}{|c}{ Collecting time } \\
\cline { 2 - 4 } & $\mathbf{1 5 / 1 2 / 0 2}$ & $\mathbf{0 4 / 0 1 / 0 3}$ & $\mathbf{2 6 / 0 1 / 0 3}$ \\
$\mathrm{A}$ & Proembryo & Globular & Torpedo \\
$\mathrm{B}$ & Torpedo & Pre-cotyledonary & Cotyledonary \\
$\mathrm{C}$ & Globular & Torpedo & Pre-cotyledonary \\
\hline
\end{tabular}

The embryogenic induction in A. angustifolia was observed after 30 days culture. This process was characterized by the extrusion of a group of friable and translucent cells starting from the embryonal apex of the zygotic embryo with a subsequent enhanced cell proliferation. In all the induction tested, the embryogenic competence was influenced by the developmental stage of the explants (Table 2), the highest rate being observed in pre-cotyledonary zygotic embryos. Explants from proembryos and globular embryos showed induction rates of 13.3 and $31.3 \%$, respectively. Zygotic embryos in cotyledonary stage resulted in low induction rates and these cultures did not show embryogenic competence (data not show). The embryogenic induction rates observed in the present work were higher than those observed in other conifer species such as Pinus taeda that presented a mean induction rate of $17.9 \%$ (Pullman et al., 2003).

The data obtained in the present work confirmed previous results with $A$. angustifolia (Guerra et al., 2000; Santos et al., 2002, Silveira et al., 2002) in which the pre-cotyledonary stage of developmental showed enhanced competence for embryogenic induction. These authors concluded that the competence for the induction of embryogenic culture was lost after the development of cotyledons. The strict requirement of juvenile explants, often of embryonic origin, indicated that re-direction of developmental programs in conifers was difficult to achieve in in vitro cultures (Stasolla et al., 2003).

The mechanism of embryogenic cultures induction is not fully understood. According to Zoglauer (2003), during the induction phase, cells cease their program of specialization and start a new developmental program. The specialization program is negatively affected by the methylation of DNA for which the auxins may play a fundamental role (Lo Schiavo et al., 1989). The carbon source and plant growth regulators supplemented to the culture medium significantly affected the embryogenic induction rate. Sucrose was superior to maltose (Table 3). Culture media supplemented with sucrose also showed an enhanced cell proliferation, specially in combination with $2,4-\mathrm{D}(5 \mu \mathrm{M})$, BAP and Kin $(2 \mu \mathrm{M}$ each). However, the supplementation of the culture medium with maltose $(3 \%)$ plus 2,4-D $(5 \mu \mathrm{M})$ and BAP and Kin $(2 \mu \mathrm{M}$ each), even resulting in a reduced cell proliferation, favored the further development of somatic pro-embryos with bipolar morphology which had their cells reactive to acetocarmine (Figure 1d). Most of the pro-embryos developed in the culture medium supplemented with sucrose were less organized showing disturbed polarity and a diffuse morphology (Figure 1c). Similar patterns were observed in Picea abies embryogenic cultures (Filonova et al., 2000).

According to Blanc (2002), the effect of maltose in the morphology and histodifferentiation of embryogenic cultures could be ascribed to the low supply of hexoses. This suggested that the slow hydrolysis of maltose was the biochemical signal conducting to the formation of somatic embryos. On the contrary, rapid hydrolysis of sucrose could increase the content of hexoses and storage compounds, directing the cells to a fast proliferation rates (Blanc, 2002), which was consistent with the results observed in the present 
work. In embryogenic cultures of A. angustifolia, the supplementation of culture medium with sucrose was an event associated with the unorganized cell proliferation, while maltose was possibly the key factor to start the organized embryonic development.

Table 2 - Percentage of embryogenic cultures of Araucaria angustifolia induced from zygotic embryos in different developmental stages in culture medium BM supplemented with maltose or sucrose.

\begin{tabular}{l|c|c}
\hline $\begin{array}{c}\text { Developmental } \\
\text { Stage }\end{array}$ & $\begin{array}{c}\text { Sample } \\
\text { Size }\end{array}$ & $\begin{array}{c}\text { Induction } \\
\text { Rate (\%) }\end{array}$ \\
\hline Pro-embryo & 180 & $13.3 \mathrm{c}$ \\
Globular & 360 & $31.3 \mathrm{~b}$ \\
Torpedo & 540 & $52.8 \mathrm{a}$ \\
Pre-cotyledonary & 360 & $66.7 \mathrm{a}$ \\
Mean & & 41.09 \\
CV $(\%)$ & & $32.9^{2}$ \\
\hline
\end{tabular}

${ }^{\mathrm{T}}$ Means followed by same letters are not statistically different according to the SNK test (5\%). 2- Data transformed to log (x+2).

Table 3 - Effect of carbon source in the induction of Araucaria angustifolia embryogenic cultures.

\begin{tabular}{l|c|c}
\hline \multicolumn{1}{c|}{ Carbon Source } & $\begin{array}{c}\text { Sample } \\
\text { Size }\end{array}$ & $\begin{array}{c}\text { Induction } \\
\text { Rate (\%) })^{\mathbf{1}}\end{array}$ \\
\hline Sucrose & 720 & $56.6 \mathrm{a}$ \\
Maltose & 720 & $35.4 \mathrm{~b}$ \\
Mean & & 46.0 \\
CV $(\%)$ & \multicolumn{2}{c}{$33.4^{2}$} \\
\hline${ }^{1}$ Means followed by same letters are not statistically different according to the SNK test (5\%). 2- Data transformed to log (x+2).
\end{tabular}

Cell morphology and embryogenic competence

Embryogenic cultures of A. angustifolia presented mainly two cell types: elongated cells, which were vacuolated (Figure 1b), and isodiametric cells, which were smaller and with a dense cytoplasm (Figure 1a). These cells were clustered into aggregates of proliferating embryogenic cultures, showing variations in size and morphology and revealing different affinity to the staining procedures. Small cells were reactive to acetocarmine and stained bright red (Figure 1a) and elongated cells were permeable to Evan's blue (Figure 1b). The positive reaction to acetocarmine (Durzan, 1988) and the formation of somatic proembryos with bipolar morphology (von Arnold et al., 1996) are features associated with the cell competence to develop complete somatic embryos after maturation treatments.

In several in vitro conifer embryogenic systems the cell morphology may be associated to the embryogenic competence (Egertsdotter and von Arnold, 1998) and the differences in the cell morphology may be influenced by the explant source and culture medium composition (Fehér et al., 2003).
In the present work, the carbon source significantly affected the induction rates and morphological organization of the embryogenic cultures. The requirement of a certain degree of morphological organization within the embryogenic culture prior to exposure to maturation treatment was also proposed in previous investigations (Jalonen and von Arnold, 1991; Bozhkov et al., 2002; Stasolla et al., 2003).

In Picea abies, embryogenic cell lines were classified in two groups based on the cell morphology (Mo et al., 1996). Cells of the group A, contained large embryogenic heads, formed complete somatic embryos in response to the maturation treatments, and cells of the group B, smaller and structurally disorganized embryogenic heads resulted in abnormal or few somatic embryos. In accordance with this classification, in the present work, two distinct cellular groups based on morphology as well as on developmental pattern were observed. Embryogenic cultures of $A$. angustifolia induced and maintained in BM medium supplemented with maltose presented bipolar morphology (type A), in that the proembryo are formed by aggregation of embryogenic 
cells attached to suspensors cells (Figure 1d). Cultures maintained in medium with sucrose presented diffused morphology (type B), in which the polarity was disturbed and the pro-embryo consisted in an embryogenic cells aggregates surrounded by suspensors cells (Figure 1c).

The developmental transition from pro-embryonic cultures to globular somatic embryos seemed to be a critical point in A. angustifolia somatic embryogenesis and the presence of maltose in the culture medium was a determinant factor for this transition leading to the histodifferentiation of subsequent developmental stages of somatic embryos.

\section{Somatic embryo development}

Embryogenic cultures of $A$. angustifolia originated in the inductive culture medium supplemented with sucrose or with maltose and plant growth regulators were responsive to the maturation treatments. Globular somatic embryos developed in culture medium supplemented with PEG (9\%) and maltose (9\%). It has been shown that the early stages of somatic embryogenesis are crucial for successful completion of the overall process. In Picea alba, even though similarities in transition process from embryogenic culture with different degree of morphological organization to complete developed somatic embryos were observed, this morphological organization limited the yield of somatic embryos (Filonova et al., 2000). Cytochemical analysis of $A$. angustifolia globular somatic embryos revealed that the suspensor cells were degraded and early somatic embryos appeared structurally organized (Figure 2c). Further developmental stages were not observed in response to the maturation treatments. Maltose and PEG were also effective in the promotion of development of late embryogenic stages of Pinus taeda (Li et al., 1998) and Pinus pinaster (Ramarosandratana et al., 2001). It was postulated that PEG generated a osmotic stress in the cells with a consequent alteration of phase change (Svobodová et al., 1999). This compound was also associated with lipid, starch and protein accumulation in somatic embryos (Misra et al., 1995). The PEG-stimulatory effects are important in order to allow the organization of developing embryos (Stasolla et al., 2003). In the present work, the presence of PEG in culture medium, although necessary for embryo development, was not sufficient for the completion of the maturation program.

Also, it has been proposed that the carbohydrates supplemented to the culture medium may play multiple roles, including the histodifferentiation of somatic embryos by means of the direct regulation of gene expression (Lipavska et al., 2000). Some authors (Finkelstein and Gibson, 2001; Leo and Shee, 2003) suggested that maltose could activate a common metabolic route with ABA. It was not clear that by which mechanism maltose promoted the development of globular somatic embryos in A. angustifolia. In the present work it was observed that the supplementation of the culture medium with maltose was fundamental for the morphological re-organization and histodifferentiation of the embryogenic competent cells leading to the developmental stage.

The transition from pro-embryogenic cultures to somatic embryo is a critical developmental event affecting the final yield of somatic embryos produced in culture. Thus, a proper understanding of the factors regulating these developmental processes would be of great value for the improvement of the overall embryogenic process.

In conclusion, in the present work we were successful in establishing in vitro conditions for the induction, stabilization and proliferation of embryogenic cultures of $A$. angustifolia as well as in describing patterns of morphogenesis and hystodifferentiation of embryogenic cultures and somatic embryos of A. angustifolia as affected by the carbohydrate source supplemented to the culture medium. The development of a complete regenerative protocol based on this morphogenetic route could be envisaged from the results obtained. The final goal is the development of biotechnological tools for the conservation and improvement of this important and endangered Brazilian species. The comparatively high rate of embryogenic induction and cell proliferation observed represent an additional advantage of this in vitro morphogenetic system for advanced studies in developmental and cell biology in plants starting from undifferentiated tissues. 


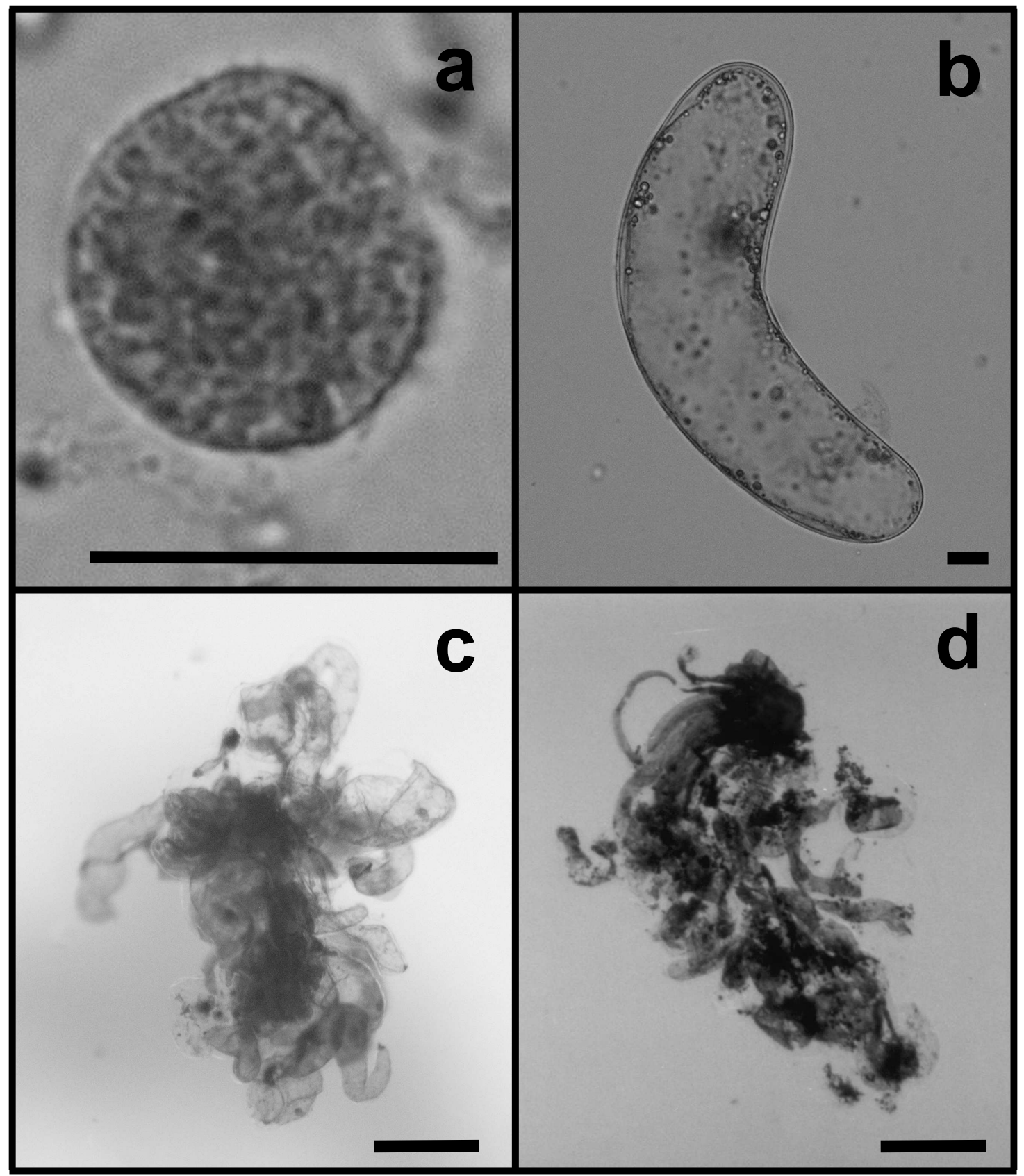

Figure 1 - Embryogenic culture of A. angustifolia stained with acetocarmine and Evan's blue. a) small isodiametric cells reactive to acetocarmine, b) elongated and vacuolated cells permeable to Evan's blue, c) Cultures maintained in BM medium with sucrose presented diffuse morphology, in that the polarity is disturbed and the pro-embryo consists in an aggregate of embryogenic cells surrounded by suspensors cells, d) embryogenic cultures induced and maintained in BM medium supplemented with maltose with bipolar morphology. The pro-embryo is formed by aggregates of embryogenic cells attached to suspensors cells (Bars $\mathrm{a}, \mathrm{b}=15 \mu \mathrm{m}$ and $\mathrm{b}, \mathrm{c}=250 \mu \mathrm{m})$. 


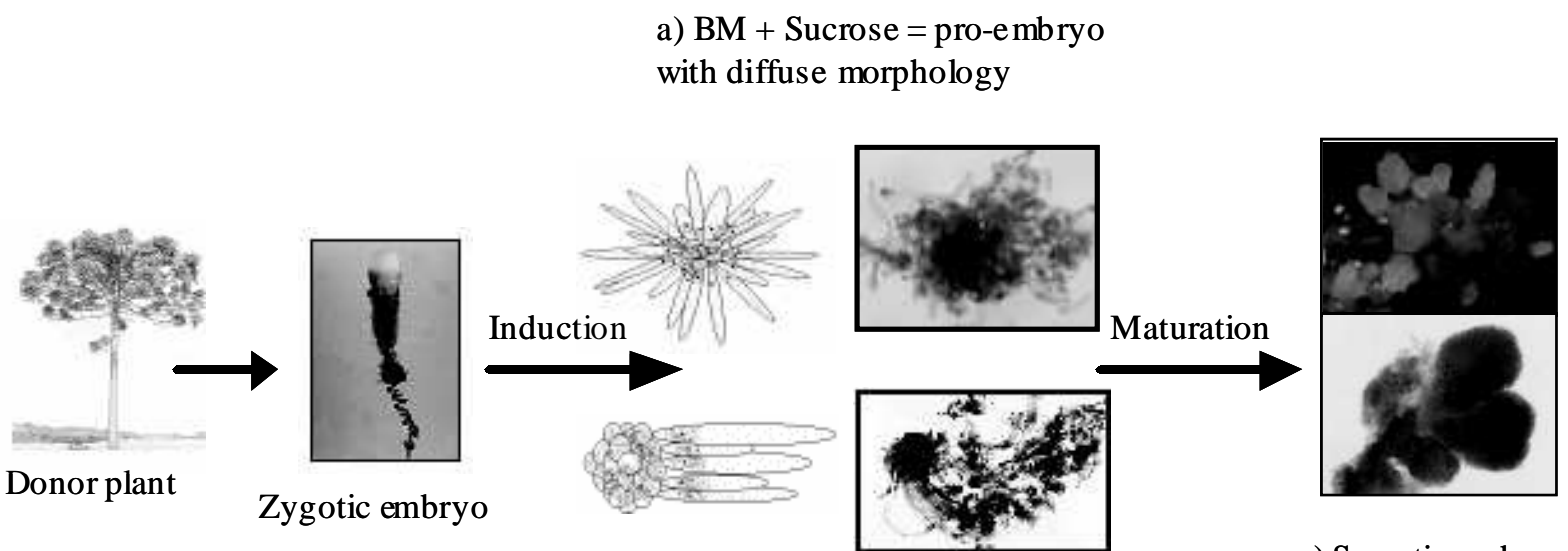

b) $\mathrm{BM}+$ Maltose = pro-e mbryo with bipolar morphology

Figure 2 - Diagram of the morphogenetic events associated to the somatic embryogenesis protocol in $A$. angustifolia. a,b) Effect of carbon source in the morphology of embryogenic cultures and hystodifferentiation of somatic embryos, c) Globular somatic embryos obtained on BM medium culture supplemented with 9\% (PEG) and (9\%) maltose.

\section{RESUMO}

No presente trabalho foram investigadas as condições para a indução, estabilização e proliferação de culturas embriogênicas de $A$. angustifolia. Foram também descritos os padrões de morfogênese e histodiferenciação de culturas embriogênicas e embriões somáticos desta espécie em resposta a diferentes fontes e concentrações de carboidratos. Embriões zigóticos no estágio précotiledonar, inoculados em meio de cultura BM, suplementados com $5 \mu \mathrm{M}$ de 2,4-D, $2 \mu \mathrm{M}$ de BAP e Kin e 3\% de maltose ou sacarose resultaram em uma taxa de indução de $66,7 \%$. A fonte de carbono afetou a taxa de indução, a multiplicação e a morfologia das culturas. Culturas embriogênicas mantidas em meio de cultura BM suplementado com maltose apresentaram morfologia bipolar. Embriões somáticos globulares foram obtidos em meio de cultura BM suplementado com PEG e maltose. Os resultados obtidos permitirão avançar na direção de um protocolo regenerativo in vitro visando à conservação e o melhoramento genético desta espécie.

\section{REFERENCES}

Astarita, L. V. and Guerra, M. P. (1998), Early somatic embryogenesis in Araucaria angustifolia - induction and maintenance of embryonal-suspensor mass cultures, Brazilian Journal of Plant Physiology, 10, 113-118.

Blanc, G.; Lardet, L.; Martin, A.; Jacob, J. L. and Carron, M. P. (2002), Differential carbohydrate metabolism conducts morphogenesis in embryogenic callus of Hevea brasiliensis (Mull. Arg.), Journal of Experimental Botany., 53, 1453-1462.

Bozhkov, P. V.; Filonova, L. H. and Von Arnold, S. (2002), A key Developmental Switch During Norway Spruce Somatic Embryogenesis is Induced by Withdrawal of Growth Regulators and Is Associated with Cell Death and Extracellular Acidification, Biotechnology and Bioengineering, 77, 6-20.

Durzan, D. J. (1988), Process control in somatic polyembryogenesis. In: Hällgren, J. E. (Ed.). Frans Symposium Department of Forest Genetics and Plant Physiology, Swedish. Proceedings... Swedish: University of Agricultural Sciences, v. 8, pp. 147-186.

Egertsdotter, U. and Von Arnold, S. (1998), Development of somatic embryos in Norway spruce, Journal Experimental Botany, 49, 155-162.

Fehér, A.; Pasternak, T. P. and Dudits, D. (2003), Transition of somatic plant cells to an embryogenic state, Plant Cell, Tissue and Organ Culture, 74, 201-228. 
Filonova, L.; Bozkov, P. and Von Arnold, S. (2000), Developmental pathway of somatic embryogenesis in Picea abies as revealed by time-lapse tracking, Journal Experimental Botany, 51, 343-249.

Finkelstein, R. R. and Gibson, S. I. (2001), ABA and sugar interactions regulating development: cross-talk or voices in a crowd?, Current Opinion in Plant Biology, 5, 26-32.

Gifford, E. M. and Foster, A. S. (1989), Coniferophyta. In: Morphology and evolution of vascular plants. New York: W. H. Freeman and Company. pp. 401-453.

Guerra, M. P.; Silveira, V.; Santos, A. L. W.; Astarita, L. V. and Nodari, R. O. (2000), Somatic embryogenesis in Araucaria angustifolia (Bert) O. Ktze. In: Jain, S.; Gupta, P. and Newton, R. (Eds.). Somatic embryogenesis in woody plants. Dordrecht: Kluwer Academic Publishers. v. 6. pp. 457-478.

Gupta, P. K. and Grob, J. (1995), Somatic embryogenesis in conifers. In: Jain, S. M.; Gupta, P. K. and Newton, R. J. (Eds.). Somatic embryogenesis in woody plant. Dordrecht: Kluwer Academic Publishers. v. 1. pp. 81-98.

Gupta, P. K. and Pullman, G. S. (1991), Method for reproducing coniferous plants by somatic embryogenesis using abscisic acid and osmotic potential variation. US Patent 5,036,007.

Jalonen, P. and Von Arnold, S. (1991), Characterization of embryogenic cell lines of Picea abies in relation to their competence for maturation. Plant Cell Reports, 10, 384-387.

Khuri, S.; Shmoury, M. R.; Baalbaki, R.; Maunder, M. and Talhouk, S. N. (2000), Conservation of the Cedrus libani populations in Lebanon: history, current status and experimental application of somatic embryogenesis, Biodiversity and Conservation, 9, 1261-1273.

Klimaszewska, K.; Bernier-Cardou, M.; Cyr, D. R. and Sutton, B. C. S. (2000), Influence of gelling agents on culture medium gel strength, water availability, tissue water potential, and maturation response in embryogenic cultures of Pinus strobus L., In Vitro Cellular and Development Biology-Plant, 36, 279-286.

Leo, P. and Shee, J. (2003), Sugar and hormone connections, Trends In Plant Science, 8, 110-116.

Li, X. Y.; Huang, F. H.; Murphy, J. B. and Gbur, E. E. (1998), Polyetilene glycol and maltose enhance somatic embryo maturation in loblolly pine (Pinus taeda L.), In Vitro Cellular and Development Biology-Plant, 34, 22-26.

Lipavská, H.; Svobodová, H.; Albrechtová J.; Kumstýrová L.; Vágner M. and Vondráková Z. (2000) Carbohydrate status during somatic embryo maturation in Norway spruce, In vitro Cellular and Development Biology - Plant, 36, 260-267.
Lo Schiavo, F.; Pitto, L.; Giuliano, G.; Nuti-Ronchi, V.; Marazziti, D.; Veraga, R.; Orselli, S. and Terzi, M. (1989), DNA methylation of embryogenic carrot cell culture and its variations as caused by maturation, differation, hormones and hypomethylation drugs, Theoretical and Applied Genetics, 77, 325-329.

Misra, S. (1995), Molecular analysis of zygotic and somatic conifer embryos, In: Jain, S. M.; Gupta, P. K. and Newton, R. J. (Eds.). Somatic embryogenesis in woody plants. Dordrecht: Kluwer Academic Publishers. v. 3. pp. 119-142.

Mo, L. H.; Egertsdotter, U. and Von Arnold, S. (1996), Secretion of specific extracellular proteins by somatic embryos of Picea abies is dependent on embryo morphology. Annals of Botany, 77, 143-152.

Pullman, G. S.; Namjoshi, K. and Zhang, Y. (2003), Somatic embryogenesis in loblolly pine (Pinus taeda L.): improving culture initiation with abscisic acid and silver nitrate. Plant Cell Reports., 22, 85-95.

Ramarosandratana, A.; Harvengt, L.; Bouvet, A.; Calvayrac, R. and Pâques, M. (2001), Effects of carbohydrate source, polyethylene glycol and gellan gun concentration on embryonal-suspensor mass (ESM) proliferation and maturation of maritime pine somatic embryos, In Vitro Cellular and Development Biology-Plant., 37, 29-34.

Reitz, P. R. and Klein, R. M. (1966), Araucariáceas. In: Reitz, P. R. (Ed.). Flora Ilustrada Catarinense. Conselho Nacional de Pesquisas Departamento de Recursos Renováveis - M. A. Herbário "Barbosa Rodrigues". pp. 1-55.

Santos, A. L. W.; Silveira, V.; Steiner, N.; Vidor, M. and Guerra, M. P. (2002), Somatic Embryogenesis in Paraná Pine (Araucaria angustifolia (Bert.) O. Kuntze), Brazilian Archives of Biology and Technology, 45, 97-106.

Silveira, V.; Steiner, N.; Santos, A. L. W.; Nodari, R. O. and Guerra, M. P. (2002), Biotechnology tolls in Araucaria angustifolia conservation and improvement: inductive factors affecting somatic embryogenesis, Crop Breeding And Applied Biotechnology, 2, 463-470.

Stasolla, C. and Yeung, E. (2003), Recent advances in conifer somatic embryogenesis: improving somatic embryos quality, Plant Cell, Tissue and Organ Culture, 74, 15-35.

Svobodová, H.; Albrechtová, J.; Kumstyrová, L.; Lipavská, H.; Vágner, M. and Vondráková, Z. (1999), Somatic embryogenesis in Norway spruce: Anatomical study of embryo development and influence of polyethylene glycol on maturation process. Plant Physiology Biochemistry, 37, 209-221.

Von Arnold, S.; Clapham, D.; Egertsdotter, U. and Mo, L. H. (1996), Somatic embryogenesis in conifers - A case study of induction and development of somatic embryos in Picea abies, Plant Growth Regulation, 20, 3-9. 
Zoglauer, K.; Behrendt, U.; Rahmat, A.; Ross, H. and Taryono (2003), Somatic embryogenesis - the gate to biotechnology in conifers. In: Laimer, M. and Rücker, W. (Eds.). Plant Tissue Culture 100 years since Gottlieb Haberlandt. New York: Springer Verlag Wien.

Received: June 23, 2004;

Revised: September 29, 2004;

Accepted: June 01, 2005. 